\title{
Ruthenium alkylidene complexes coordinated with tricyclohexylphosphine and heterocyclic $\mathbf{N}$-donor ligands
}

\author{
Tina M. Trnka, Eric L. Dias, Michael W. Day, and Robert H. Grubbs* \\ Arnold and Mabel Beckman Laboratory of Chemical Synthesis, Division of Chemistry and \\ Chemical Engineering, California Institute of Technology, Pasadena, CA 91125, U.S.A. \\ E-mail: rhg@cco.caltech.edu
}

\author{
Dedicated to Professor Gerasimos J. Karabatsos \\ (received 28 Feb 03; accepted 04 Jun 03; published on the web 13 Jun 03)
}

\begin{abstract}
Reactions of the bis(tricyclohexylphosphine) ruthenium alkylidene complexes $\left(\mathrm{PCy}_{3}\right)_{2}(\mathrm{Cl})_{2}$ $\mathrm{Ru}=\mathrm{CHPh}, \quad\left(\mathrm{PCy}_{3}\right)_{2}(\mathrm{Cl})_{2} \mathrm{Ru}=\mathrm{CHCH}=\mathrm{CPh}_{2}$, and $\left(\mathrm{PCy}_{3}\right)_{2}(\mathrm{Cl})_{2} \mathrm{Ru}=\mathrm{CHCH}=\mathrm{CMe}_{2}$ with excess pyridine (py) cleanly furnish the six-coordinate bis(pyridine) derivatives $\left(\mathrm{PCy}_{3}\right)(\mathrm{py})_{2}(\mathrm{Cl})_{2}{ }^{-}$ $\mathrm{Ru}=\mathrm{CHPh},\left(\mathrm{PCy}_{3}\right)(\mathrm{py})_{2}(\mathrm{Cl})_{2} \mathrm{Ru}=\mathrm{CHCH}=\mathrm{CPh}_{2}$, and $\left(\mathrm{PCy}_{3}\right)(\text { py })_{2}(\mathrm{Cl})_{2} \mathrm{Ru}=\mathrm{CHCH}=\mathrm{CMe}_{2}$, respectively. In solution, there is evidence for an equilibrium between $\left(\mathrm{PCy}_{3}\right)(\mathrm{py})_{2}(\mathrm{Cl})_{2}-\mathrm{Ru}=\mathrm{CHPh}$ and a five-coordinate mono(pyridine) derivative, $\left(\mathrm{PCy}_{3}\right)(\mathrm{py})(\mathrm{Cl})_{2} \mathrm{Ru}=\mathrm{CHPh}$. This mono(pyridine) complex can be isolated by heating $\left(\mathrm{PCy}_{3}\right)(\mathrm{py})_{2}(\mathrm{Cl})_{2} \mathrm{Ru}=\mathrm{CHPh}$ in toluene under dynamic vacuum to remove dissociated pyridine as a toluene azeotrope. The diphenylvinylcarbene complex $\left(\mathrm{PCy}_{3}\right)(\mathrm{py})_{2}(\mathrm{Cl})_{2} \mathrm{Ru}=\mathrm{CHCH}=\mathrm{CPh}_{2}$ has been structurally characterized by X-ray diffraction, and it exhibits a vinylcarbene ligand tilted by $\sim 30^{\circ}$ with respect to the $\mathrm{Cl}(1)-\mathrm{Ru}-$ $\mathrm{Cl}(2)-\mathrm{C}(1)$ plane. In addition, the $\mathrm{Ru}-\mathrm{N}$ bond located trans to the vinylcarbene is elongated by a substantial $0.136(2) \AA$ in comparison to the $\mathrm{Ru}-\mathrm{N}$ bond located trans to the tricyclohexylphosphine. The dimethyl-vinylcarbene derivative $\left(\mathrm{PCy}_{3}\right)(\mathrm{py})_{2}(\mathrm{Cl})_{2} \mathrm{Ru}=\mathrm{CHCH}=\mathrm{CMe}_{2}$ can be isolated as well, but it decom-poses rapidly when redissolved. Surprisingly, reaction of $\left(\mathrm{PCy}_{3}\right)_{2}(\mathrm{Cl})_{2} \mathrm{Ru}=\mathrm{CHPh}$ with 1-methyl-imidazole $(1-\mathrm{MeIm})$ follows a different route and provides the cationic tris(imidazole) product $\left[\left(\mathrm{PCy}_{3}\right)(1-\mathrm{MeIm})_{3}(\mathrm{Cl}) \mathrm{Ru}=\mathrm{CHPh}\right][\mathrm{Cl}]$, which also has been structurally characterized. These new compounds are interesting examples of ruthenium alkylidene complexes coordinated with hetero-cyclic N-donor ligands, but they display mediocre catalytic activity for the ring-closing metathesis of diethyl diallylmalonate.
\end{abstract}

Keywords: Carbene complexes, homogeneous catalysis, olefin metathesis, nitrogen heterocycles 


\section{Introduction}

As part of our efforts to develop improved olefin metathesis catalysts, we are interested in studying the effects of diverse ligands on the properties of ruthenium alkylidene complexes. For the class of $\mathrm{L}_{2} \mathrm{X}_{2} \mathrm{Ru}=\mathrm{CHR}$ complexes, the $\mathrm{X}$ - and L-type ancillary ligands can be varied, as well as the substituents on the functional alkylidene ligand. $\mathrm{We}^{1-9}$ and others ${ }^{10-12}$ have found that changes in this ligand sphere can have profound and largely unpredictable effects on catalytic activity, stability, and selectivity. ${ }^{13}$ Several examples are illustrated in Figure 1: in comparison to $\left(\mathrm{PCy}_{3}\right)_{2}(\mathrm{Cl})_{2} \mathrm{Ru}=\mathrm{CHPh}(\mathbf{1})$ or $\left(\mathrm{PCy}_{3}\right)_{2}(\mathrm{Cl})_{2} \mathrm{Ru}=\mathrm{CHCH}=\mathrm{CPh}_{2}$, the diiodide derivative exhibits enhanced initiation properties, ${ }^{2}$ the $\mathrm{N}$-heterocyclic carbene derivative displays increased catalytic propagation rates, ${ }^{3,14}$ and the Schiff-base derivative displays greater thermal stability. ${ }^{4}$
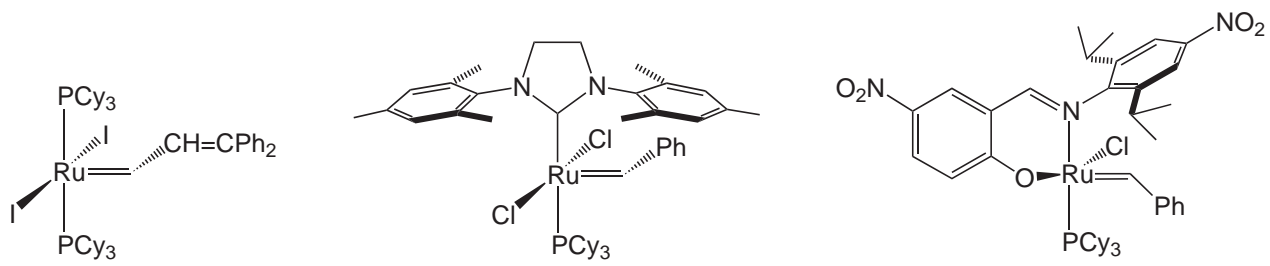

Figure 1. Variations in the ligand sphere of ruthenium alkylidene olefin metathesis catalysts.

Previous work has shown that the reaction of $\left(\mathrm{PPh}_{3}\right)_{2}(\mathrm{TFA})_{2} \mathrm{Ru}=\mathrm{CHCH}=\mathrm{CPh}_{2}(\mathrm{TFA}=$ trifluoroacetate) with 1-vinylimidazole initially produces a mono(imidazole) species in which the imidazole is coordinated trans to the vinylcarbene ligand (Scheme 1). ${ }^{5}$ However, the ultimate product is the bis(imidazole) complex $\left(\mathrm{PPh}_{3}\right)(1 \text {-vinylimidazole })_{2}(\mathrm{TFA})_{2} \mathrm{Ru}=\mathrm{CHCH}=\mathrm{CPh}_{2}$. This result provided the first evidence that heterocyclic $\mathrm{N}$-donor ligands could be used to stabilize ruthenium alkylidene complexes, albeit in a coordinatively- and electronically-saturated example. We have extended this study to the bis(tricyclohexylphosphine) dichloride system $\left(\mathrm{PCy}_{3}\right)_{2}(\mathrm{Cl})_{2}-\mathrm{Ru}=\mathrm{CHR}\left(\mathrm{R}=\mathrm{Ph}, \mathrm{CHCPh}_{2}, \mathrm{CHCMe}_{2}\right)$, and in this paper, we describe several new ruthenium alkylidene complexes coordinated with pyridine and imidazole ligands.

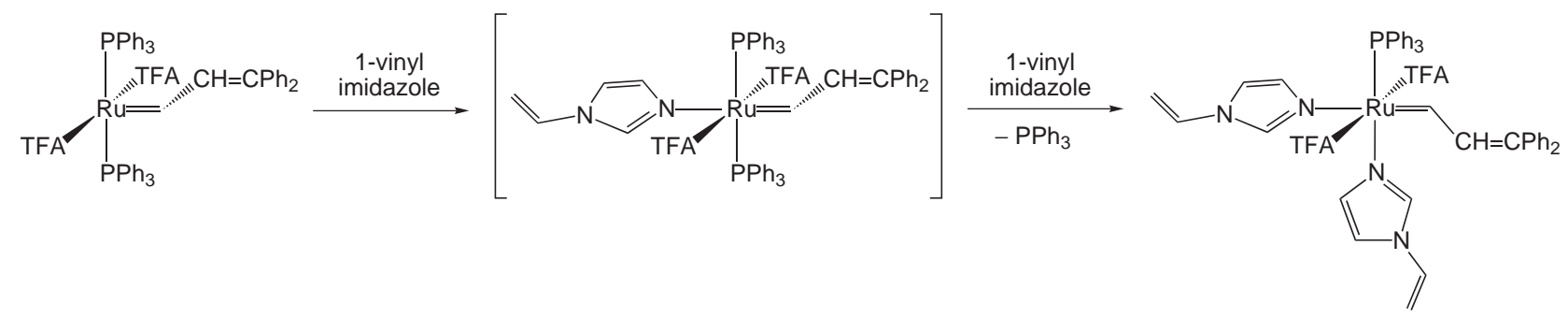

Scheme 1. Reaction of $\left(\mathrm{PPh}_{3}\right)_{2}(\mathrm{TFA})_{2} \mathrm{Ru}=\mathrm{CHCH}=\mathrm{CPh}_{2}$ (TFA = trifluoroacetate $)$ with 1-vinylimidazole. 


\section{Results and Discussion}

\section{Pyridine-coordinated ruthenium benzylidene complexes}

Reaction of $\left(\mathrm{PCy}_{3}\right)_{2}(\mathrm{Cl})_{2} \mathrm{Ru}=\mathrm{CHPh}(\mathbf{1})^{6}$ with an excess of pyridine (py) cleanly furnishes the 18 electron bis(pyridine) complex $\left(\mathrm{PCy}_{3}\right)(\mathrm{py})_{2}(\mathrm{Cl})_{2} \mathrm{Ru}=\mathrm{CHPh}$ (2) (Scheme 2). The ${ }^{1} \mathrm{H} \mathrm{NMR}$ spectrum of 2 contains a characteristic downfield doublet for the benzylidene proton at $\delta 19.9$ with coupling to the remaining tricyclohexylphosphine ligand $\left({ }^{3} J_{\mathrm{HP}}=12 \mathrm{~Hz}\right)$. The ${ }^{31} \mathrm{P}\left\{{ }^{1} \mathrm{H}\right\} \mathrm{NMR}$ spectrum consists of a single, sharp peak at $\delta$ 37.7. Although the ${ }^{1} \mathrm{H}$ NMR signals for the pyridine ligands are broadened, integration of the aromatic region (15 protons) indicates that two equivalents of pyridine are present.

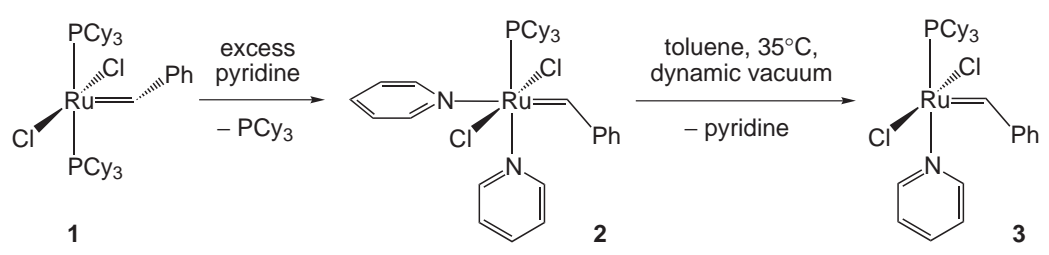

Scheme 2. Reaction of $\left(\mathrm{PCy}_{3}\right)_{2}(\mathrm{Cl})_{2} \mathrm{Ru}=\mathrm{CHPh}$ with pyridine.

Variable temperature ${ }^{1} \mathrm{H}$ NMR provides further insight into the nature of complex 2 . At $-50^{\circ} \mathrm{C}$, the $\mathrm{Ru}=\mathrm{CH}_{\alpha}$ resonance appears at $\delta 20.5$, and when the temperature is increased to $60{ }^{\circ} \mathrm{C}$, it shifts upfield to $\delta$ 19.8. Such a large change in chemical shift as a function of temperature is consistent with an equilibrium situation, in this case between the bis(pyridine) complex $\left(\mathrm{PCy}_{3}\right)(\mathrm{py})_{2}(\mathrm{Cl})_{2} \mathrm{Ru}=\mathrm{CHPh}(2)$ (dominant at lower temperature) and a mono(pyridine) complex, $\left(\mathrm{PCy}_{3}\right)(\mathrm{py})(\mathrm{Cl})_{2} \mathrm{Ru}=\mathrm{CHPh}$ (3) (dominant at higher temperature). To verify this conclusion, a solution of 2 in toluene was heated at $35{ }^{\circ} \mathrm{C}$ under dynamic vacuum to remove dissociated pyridine as a toluene azeotrope. The product obtained by this method exhibits a ${ }^{1} \mathrm{H}$ NMR resonance at $\delta 19.8$ that is consistent with 3 (Scheme 2). Furthermore, integration of the aromatic region indicates that only one equivalent of pyridine is present. The ${ }^{31} \mathrm{P}\left\{{ }^{1} \mathrm{H}\right\} \mathrm{NMR}$ spectrum consists of a sharp resonance at $\delta 38.4$, which is shifted slightly downfield compared to 2. Addition of excess pyridine- $d_{5}$ to this sample results in an immediate change from darker to lighter green, and the re-formation of $\mathbf{2}$ is indicated by the shift of the $\mathrm{Ru}=\mathrm{CH}_{\alpha}$ resonance back downfield ( $\delta$ 20.4).

Reaction of 1 with an excess of dimethylaminopyridine (DMAP) provides the analogous bissubstituted product $\left(\mathrm{PCy}_{3}\right)(\mathrm{DMAP})_{2}(\mathrm{Cl})_{2} \mathrm{Ru}=\mathrm{CHPh}$. However, this complex has not been isolated because of co-precipitation with excess DMAP, and only partial conversion to $\left(\mathrm{PCy}_{3}\right)(\mathrm{DMAP})_{2}(\mathrm{Cl})_{2} \mathrm{Ru}=\mathrm{CHPh}$ occurs if two equivalents of DMAP are used. Similar reactions of 1 with 2-methylpyridine, 2,6-dimethylpyridine, and perfluoropyridine were unsuccessful. In these cases, the equilibrium for phosphine displacement presumably is unfavorable because of steric interactions with the ortho methyl substituents in 2-methylpyridine and 2,6dimethylpyridine, and the electronic deactivation of perfluoropyridine. 


\section{Pyridine-coordinated ruthenium vinylcarbene complexes}

As illustrated in Scheme 3, reaction of the diphenylvinylcarbene complex $\left(\mathrm{PCy}_{3}\right)_{2}(\mathrm{Cl})_{2}$ $\mathrm{Ru}=\mathrm{CHCH}=\mathrm{CPh}_{2}(4)^{15}$ with excess pyridine furnishes the bis(pyridine) product $\left(\mathrm{PCy}_{3}\right)(\mathrm{py})_{2}$ $(\mathrm{Cl})_{2} \mathrm{Ru}=\mathrm{CHCH}=\mathrm{CPh}_{2}(\mathbf{5})$. Like the benzylidene derivative 2, complex 5 is characterized by a ${ }^{1} \mathrm{H}$ NMR doublet at $\delta 20.2\left({ }^{3} J_{\mathrm{HP}}=12 \mathrm{~Hz}\right)$ for the $\mathrm{Ru}=\mathrm{CH}_{\alpha}$ proton, a ${ }^{13} \mathrm{C}\left\{{ }^{1} \mathrm{H}\right\}$ NMR resonance at $\delta$ 312.7 for the carbene carbon, and a ${ }^{31} \mathrm{P}\left\{{ }^{1} \mathrm{H}\right\}$ NMR resonance at $\delta 30.2$ for the tricyclohexylphosphine ligand. The vinyl proton appears as a doublet at $\delta 8.8\left({ }^{3} J_{\mathrm{HH}}=12 \mathrm{~Hz}\right)$.

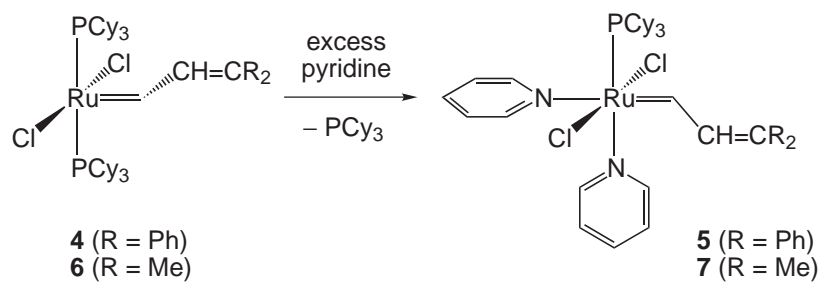

Scheme 3. Reactions of two ruthenium vinylcarbene derivatives $\left(\mathrm{PCy}_{3}\right)_{2}(\mathrm{Cl})_{2} \mathrm{Ru}=\mathrm{CHCH}=\mathrm{CR}_{2}$ with pyridine.

The crystal structure of $\mathbf{5}$ is shown in Figure 2. The diphenylvinylcarbene ligand $[\mathrm{C}(1)-\mathrm{C}(2)-\mathrm{C}(3)]$ is tilted $\sim 30^{\circ}$ out of the $\mathrm{Cl}(1)-\mathrm{Ru}-\mathrm{Cl}(2)-\mathrm{C}(1)$ plane, with the diphenyl substituent directed away from the tricyclohexylphosphine. In comparison, the vinylcarbene moiety in the structure of $\left(\mathrm{PCy}_{3}\right)_{2}(\mathrm{Cl})_{2} \mathrm{Ru}=\mathrm{CHCH}=\mathrm{CPh}_{2}$ (4) is oriented fully in the $\mathrm{Cl}-\mathrm{Ru}-\mathrm{Cl}-\mathrm{C}_{\alpha}$ plane, ${ }^{15}$ whereas in the structures of $\left(\mathrm{PPh}_{3}\right)_{2}(\mathrm{Cl})_{2} \mathrm{Ru}=\mathrm{CHCH}=\mathrm{CPh}_{2}$ and $\left(\mathrm{PPh}_{3}\right)_{2}(\mathrm{Cl})_{2}-\mathrm{Ru}=\mathrm{CHCH}=\mathrm{CMe}_{2},{ }^{7,16}$ it is oriented fully in the $\mathrm{P}-\mathrm{Ru}-\mathrm{P}-\mathrm{C}_{\alpha}$ plane. These changes likely are due to the different steric requirements of the pyridine and phosphine ligands. Another notable feature is that the $\mathrm{Ru}-\mathrm{N}$ bond located trans to the vinylcarbene is significantly longer [by $0.136(2) \AA]$ than that located trans to the tricyclohexylphosphine. A similar effect occurs in $\left(\mathrm{H}_{2} \mathrm{IMes}\right)(\mathrm{py})_{2}-(\mathrm{Cl})_{2} \mathrm{Ru}=\mathrm{CHPh}\left(\mathrm{H}_{2} \mathrm{IMes}=1,3\right.$-dimesitylimidazolidine-2-ylidene $)$ and can be ascribed to the strong trans influence of the alkylidene ligand. ${ }^{17}$

Reaction of $\left(\mathrm{PCy}_{3}\right)_{2}(\mathrm{Cl})_{2} \mathrm{Ru}=\mathrm{CHCH}=\mathrm{CMe}_{2}(6)^{18}$ with pyridine provides the dimethylvinylcarbene derivative $\left(\mathrm{PCy}_{3}\right)(\mathrm{py})_{2}(\mathrm{Cl})_{2} \mathrm{Ru}=\mathrm{CHCH}=\mathrm{CMe}_{2}(7)$ (Scheme 3), but this isolated material decomposes within one hour at room temperature when redissolved in $\mathrm{C}_{6} \mathrm{D}_{6}$. As a result, 7 has been characterized only by ${ }^{1} \mathrm{H}$ and ${ }^{31} \mathrm{P}\left\{{ }^{1} \mathrm{H}\right\}$ NMR spectroscopy. The ${ }^{1} \mathrm{H}$ NMR spectrum of 7 is similar to 5 except for the absence of the phenyl resonances and the presence of two methyl signals at $\delta 1.26$ and 0.75 . Although previous work has shown that the dimethylvinylcarbene ligand can be deprotonated to yield vinylvinyl species, ${ }^{19}$ this product is not present in the decomposition mixture of 7 . The only identifiable byproduct is free pyridine. 


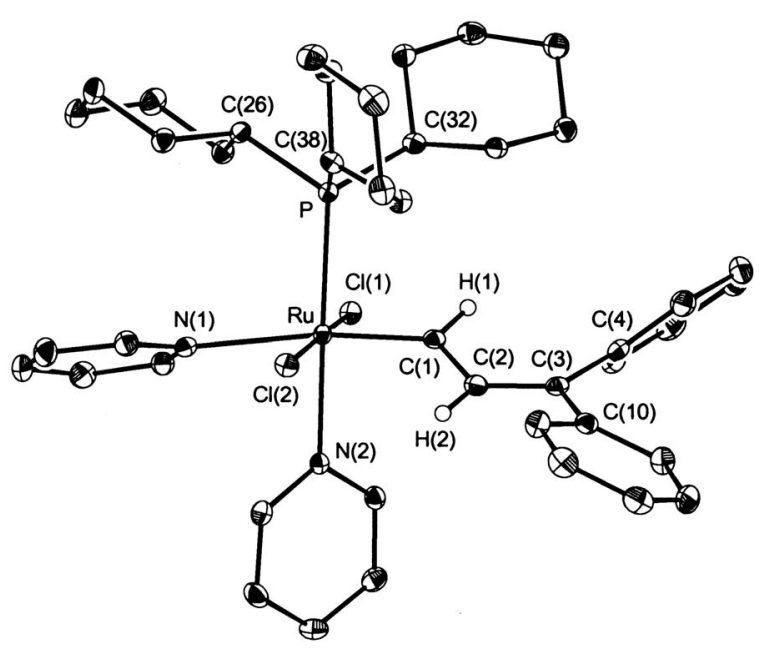

Figure 2. Structure of $\left(\mathrm{PCy}_{3}\right)(\mathrm{py})_{2}(\mathrm{Cl})_{2} \mathrm{Ru}=\mathrm{CHCH}=\mathrm{CPh}_{2}(5) \cdot \mathrm{py}$. For clarity, solvent and hydrogen atoms have been omitted, except $\mathrm{H}(1)$ and $\mathrm{H}(2)$. Displacement ellipsoids are drawn at $50 \%$ probability; hydrogen atoms are drawn at arbitrary scale. Selected bond distances $[\AA]$ and angles [deg]: $\mathrm{Ru}-\mathrm{C}(1)$ 1.877(2), Ru-N(1) 2.319(1), Ru-N(2) 2.183(1), Ru-P 2.3743(4), Ru$\mathrm{Cl}(1) 2.4128(4), \mathrm{Ru}-\mathrm{Cl}(2)$ 2.3939(4), C(1)-C(2) 1.426(2), C(2)-C(3) 1.366(2), C(3)-C(4) 1.482(2), C(3)-C(10) 1.486(2), P-C(26) 1.865(2), P-C(32) 1.872(2), P-C(38) 1.859(2), C(1)$\mathrm{Ru}-\mathrm{N}(1)$ 171.76(6), Cl(1)-Ru-Cl(2) 174.92(1), N(2)-Ru-P 177.89(4), Ru-C(1)-C(2) 126.7(1), $\mathrm{C}(1)-\mathrm{C}(2)-\mathrm{C}(3) 127.6(2), \mathrm{C}(4)-\mathrm{C}(3)-\mathrm{C}(10) 118.0(1)$.

\section{Imidazole-coordinated ruthenium benzylidene complexes}

Surprisingly, reaction of $\left(\mathrm{PCy}_{3}\right)_{2}(\mathrm{Cl})_{2} \mathrm{Ru}=\mathrm{CHPh}(\mathbf{1})$ with 1 -methylimidazole $(1-\mathrm{MeIm})$ does not provide $\left(\mathrm{PCy}_{3}\right)(1-\mathrm{MeIm})_{2}(\mathrm{Cl})_{2} \mathrm{Ru}=\mathrm{CHPh}$ by analogy to the transformation in Scheme 1 , but instead yields the cationic tris(imidazole) complex $\left[\left(\mathrm{PCy}_{3}\right)(1-\mathrm{MeIm})_{3}(\mathrm{Cl}) \mathrm{Ru}=\mathrm{CHPh}\right][\mathrm{Cl}](8)$ (Scheme 4). By ${ }^{1} \mathrm{H} \mathrm{NMR}$, this unexpected product features a $\mathrm{Ru}=\mathrm{CH}_{\alpha}$ resonance at $\delta 20.42(\mathrm{~d}$, ${ }^{3} J_{\mathrm{HP}}=11 \mathrm{~Hz}$ ), as well as two methyl resonances at $\delta 3.70$ and 3.53 in a 2:1 ratio, which are consistent with two equivalent and one inequivalent 1-MeIm ligands. Complex 8 also exhibits a distinctive ${ }^{13} \mathrm{C}\left\{{ }^{1} \mathrm{H}\right\}$ NMR resonance at $\delta 324.97$ for the carbene carbon and a ${ }^{31} \mathrm{P}\left\{{ }^{1} \mathrm{H}\right\} \mathrm{NMR}$ resonance at $\delta 22.77$ for the tricyclohexylphosphine ligand. This product is insoluble in aromatic solvents but soluble in chlorinated solvents and methanol.

In the formation of $\mathbf{8}$, halide abstraction or displacement is achieved by the neutral 1methylimidazole ligand. The mild conditions for this transformation are uncommon but not unprecedented for other substitutionally labile ruthenium precursors; for example, reaction of (binap) $\left(\mathrm{PPh}_{3}\right)(\mathrm{Cl})_{2} \mathrm{Ru}$ with acetonitrile at room temperature provides the cationic tris(acetonitrile) complex $\left[(\right.$ binap $\left.)(\mathrm{MeCN})_{3}(\mathrm{Cl}) \mathrm{Ru}\right][\mathrm{Cl}] .{ }^{19}$ In comparison, other cationic ruthenium carbene complexes, such as $\left[(\mathrm{Tp})\left(\mathrm{PCy}_{3}\right)\left(\mathrm{H}_{2} \mathrm{O}\right) \mathrm{Ru}=\mathrm{CHPh}\right]\left[\mathrm{BF}_{4}\right]$ and $[(p$ cymene $\left.)\left(\mathrm{PPh}_{3}\right)(\mathrm{Cl})-\mathrm{Ru}=\mathrm{C}=\mathrm{C}=\mathrm{CPh}_{2}\right]\left[\mathrm{PF}_{6}\right]$, ${ }^{8,21}$ typically are synthesized by the abstraction of a halide ligand with $\mathrm{Ag}^{+}$. 


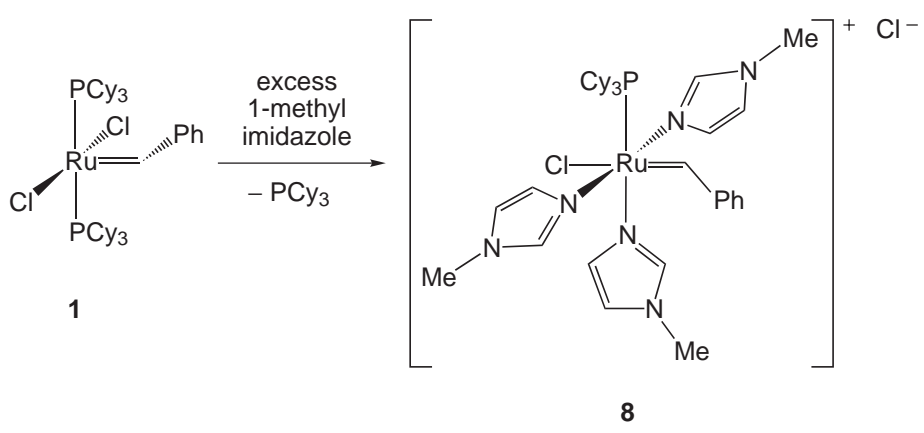

Scheme 4. Reaction of $\left(\mathrm{PCy}_{3}\right)_{2}(\mathrm{Cl})_{2} \mathrm{Ru}=\mathrm{CHPh}$ with 1-methylimidazole.

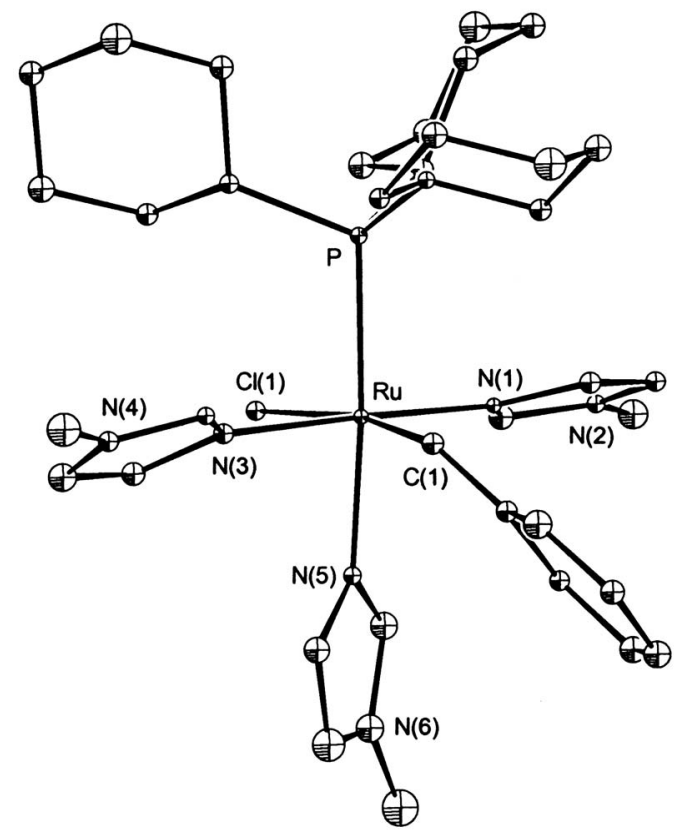

Figure 3. Structure of the cationic portion of $\left[(\mathrm{PCy} 3)(1-\mathrm{MeIm})_{3}(\mathrm{Cl}) \mathrm{Ru}=\mathrm{CHPh}\right][\mathrm{Cl}](\mathbf{8}) \cdot 2.21$ $\mathrm{CH}_{2} \mathrm{Cl}_{2}$ (molecule A). For clarity, solvent molecules and hydrogen atoms have been omitted. Isotropic displacement ellipsoids are drawn at 50\% probability. Selected bond distances $[\AA]$ and angles [deg]: Ru-C(1) 1.887(6), Ru-N(1) 2.109(5), Ru-N(3) 2.113(5), Ru-N(5) 2.138(6), Ru$\mathrm{Cl}(1)$ 2.582(2), Ru-P 2.408(2), P-C(20) 1.853(6), P-C(26) 1.859(7), P-C(32) 1.870(7), N(1)$\mathrm{Ru}-\mathrm{N}(3)$ 176.4(2), P-Ru-N(5) 175.8(2), C(1)-Ru-Cl(1) 170.7(2).

The identity of $\mathbf{8}$ was confirmed by X-ray diffraction (Figure 3). Unfortunately, the quality of this structure is poor because the crystal was twinned and contained multiple disordered dichloromethane solvent molecules. The $\mathrm{Ru}=\mathrm{C}$ distance in 8 [1.874(6) $\AA$ (average values for molecules A and B)] is somewhat longer than is usually found in neutral, five-coordinate ruthenium benzylidene complexes [e.g., 1.838(2) $\AA$ in 1]. This trend also has been observed in the related complex $\left[(\mathrm{Tp})\left(\mathrm{PCy}_{3}\right)\left(\mathrm{H}_{2} \mathrm{O}\right) \mathrm{Ru}=\mathrm{CHPh}\right]\left[\mathrm{BF}_{4}\right][1.878(4) \AA] .{ }^{8}$ The $\mathrm{Ru}-\mathrm{Cl}$ distance [2.570(2) $\AA(\operatorname{avg~A}$ and B)] is substantially elongated compared to those in 1 [2.390(1) $\AA$ (avg)], 
presumably because of the electronic impact of the trans benzylidene ligand. The $\mathrm{Cl}-\mathrm{Ru}-\mathrm{C}(1)$ angle is distorted by $\sim 10^{\circ}$ from linearity away from the bulky tricyclohexylphosphine ligand. The $\mathrm{Ru}-\mathrm{N}(1)$ and $\mathrm{Ru}-\mathrm{N}(3)$ distances [2.114(5) and 2.110(5) $\AA$, respectively (avg $\mathrm{A}$ and $\mathrm{B}$ )] are within the range of $\mathrm{Ru}-\mathrm{N}$ distances in the homoleptic 1methylimidazole dication $\left[(1-\mathrm{MeIm})_{6} \mathrm{Ru}\right]^{2+}[2.098(4)-2.113(4) \AA] .{ }^{21}$ However, the $\mathrm{Ru}-\mathrm{N}(5)$ bond located trans to the tricyclohexylphosphine ligand is elongated by $\sim 0.02 \AA$. This distance [2.140(6) (avg A and B)] is comparable to that for a similar $\mathrm{Ru}-\mathrm{N}$ bond [2.131(7) $\AA$ ] situated trans to the triphenylphosphine ligand in $\left(\mathrm{PPh}_{3}\right)(1-\mathrm{MeIm})_{2}(\mathrm{Cl})_{3} \mathrm{Ru}^{23}$

A similar transformation using 1,5-dicyclohexylimidazole provides $\left[\left(\mathrm{PCy}_{3}\right)(1,5\right.$-dicyclohexylimidazole $\left.)_{3}(\mathrm{Cl}) \mathrm{Ru}=\mathrm{CHPh}\right][\mathrm{Cl}]$, but no reaction occurs with more sterically hindered imidazoles, such as 1,3,4-triphenyl-2-methylimidazole. In the case of 1,2-dimethylimidazole, several new species appear as small doublets in the $\mathrm{Ru}=\mathrm{CH}_{\alpha}$ region of the ${ }^{1} \mathrm{H}$ NMR spectrum, but these decompose within a day in solution at room temperature.

\section{Olefin metathesis activity}

We reasoned that as a potential olefin metathesis catalyst, complex $\mathbf{3}$ might have enhanced initiation properties in comparison to $\mathbf{1}$ because of the expected greater lability of the pyridine ligand. According to our mechanistic model, ${ }^{14}$ initiation involves formation of the 14 -electron intermediate $\left(\mathrm{PCy}_{3}\right)(\mathrm{Cl})_{2} \mathrm{Ru}=\mathrm{CHPh}$, which then enters the catalytic cycle (Figure 4).

Upon addition of 25 equivalents of diethyl diallylmalonate to a solution of $\mathbf{3}$, the color immediately changes from green to orange. After 15 minutes at room temperature, ${ }^{1} \mathrm{H}$ NMR spectroscopy indicates that $\sim 20 \%$ of the substrate is converted to the ring-closed product, but no $\mathrm{Ru}=\mathrm{CH}_{\alpha}$-containing species are present and the reaction does not continue. These observations suggest that within this time, all of $\mathbf{3}$ enters the catalytic cycle, consistent with fast initiation, but the active species does not continue to propagate for more than a few turnovers. In an effort to stabilize the propagating alkylidene and methylidene species (Figure 4), the experiment was repeated in the presence of ten equivalents of pyridine. After 35 minutes at room temperature, the ${ }^{1} \mathrm{H}$ NMR spectrum shows only $\sim 10 \%$ conversion and the presence of complex 2 (possibly as part of an average of $\mathbf{2}$ and $\mathbf{3}$ ). Heating at $38^{\circ} \mathrm{C}$ for 30 minutes provides an additional $10 \%$ of ring-closed product, but all $\mathrm{Ru}=\mathrm{CH}_{\alpha}$ signals disappear within this time and the reaction does not continue. Thus, we conclude that even though $\mathbf{3}$ initiate more quickly than $\mathbf{1}$, the propagating species are unstable under these conditions and decompose rapidly. The presence of excess pyridine decreases initiation, presumably by formation of the bis(pyridine) complex 2 in situ.

We also tested complex $\mathbf{8}$ in the ring-closing metathesis of diethyl diallylmalonate. With a catalyst loading of $5 \mathrm{~mol} \%$ in $0.05 \mathrm{M} \mathrm{CD}_{2} \mathrm{Cl}_{2}$, the reaction went to $52 \%$ conversion after 2.5 hours at $40^{\circ} \mathrm{C}$. At this time, no carbene $\mathrm{H}_{\alpha}$ signals were present and the reaction did not continue, which is consistent with catalyst decomposition. 


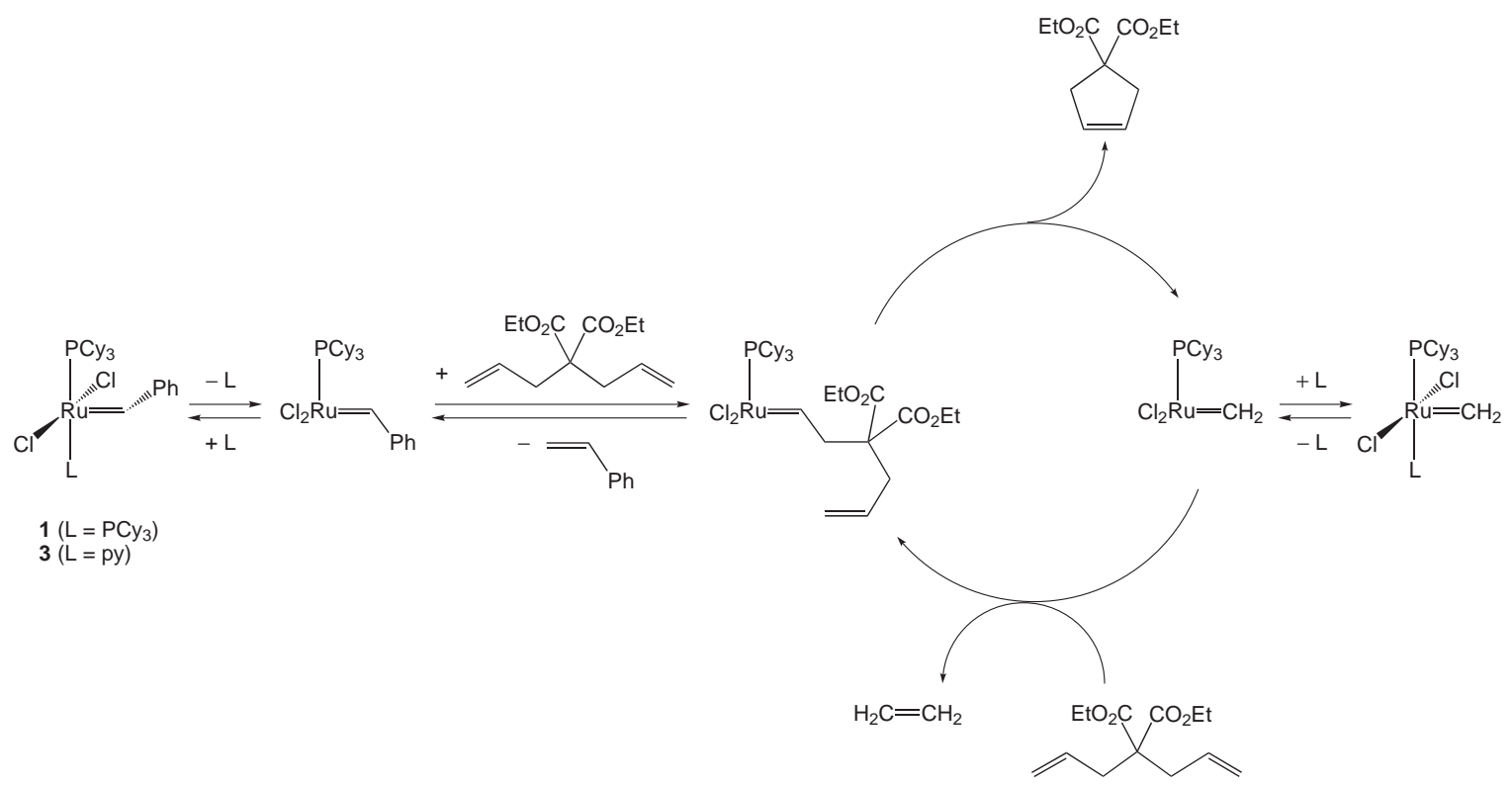

Figure 4. The ring-closing metathesis of diethyl diallylmalonate with catalysts 1 or $\mathbf{3}$.

\section{Conclusions}

In this study, we have synthesized several new ruthenium alkylidene complexes coordinated with tricyclohexylphosphine, pyridine, and imidazole ligands. The six-coordinate bis(pyridine) derivatives $\left(\mathrm{PCy}_{3}\right)(\mathrm{py})_{2}(\mathrm{Cl})_{2} \mathrm{Ru}=\mathrm{CHPh}(\mathbf{2}),(\mathrm{PCy})_{3}(\mathrm{py})_{2}(\mathrm{Cl})_{2} \mathrm{Ru}=\mathrm{CHCH}=\mathrm{CPh}_{2}$ (5), and $\left(\mathrm{PCy}_{3}\right)$ (py) ${ }_{2}(\mathrm{Cl})_{2} \mathrm{Ru}=\mathrm{CHCH}=\mathrm{CMe}_{2}(7)$ are readily accessible by the addition of excess pyridine to the bis(tricyclohexylphosphine) precursors. These substitution reactions of one phosphine ligand with two pyridine ligands most likely occur through an associative mechanism, by analogy to the conversions of $\left(\mathrm{PPh}_{3}\right)_{2}(\mathrm{TFA})_{2} \mathrm{Ru}=\mathrm{CHCH}=\mathrm{CPh}_{2} \quad$ to $\quad\left(\mathrm{PPh}_{3}\right)(1 \text {-vinylimidazole })_{2}(\mathrm{TFA})_{2^{-}}$ $\mathrm{Ru}=\mathrm{CHCH}=\mathrm{CPh}_{2} \quad\left(\right.$ Scheme 1) and $\left(\mathrm{H}_{2} \mathrm{IMes}\right)\left(\mathrm{PCy}_{3}\right)(\mathrm{Cl})_{2} \mathrm{Ru}=\mathrm{CHPh}$ to $\left(\mathrm{H}_{2} \mathrm{IMes}\right)(\mathrm{py})_{2}(\mathrm{Cl})_{2}-$ $\mathrm{Ru}=\mathrm{CHPh} .{ }^{5,17}$ In this mechanism, one pyridine first binds trans to the alkylidene, followed by phosphine dissociation and coordination of the second pyridine.

In solution, there is evidence for an equilibrium between $\left(\mathrm{PCy}_{3}\right)(\mathrm{py})_{2}(\mathrm{Cl})_{2} \mathrm{Ru}=\mathrm{CHPh}(2)$ and the five-coordinate mono(pyridine) derivative, $\left(\mathrm{PCy}_{3}\right)(\mathrm{py})(\mathrm{Cl})_{2} \mathrm{Ru}=\mathrm{CHPh}(3)$, which can be isolated. However, under turnover conditions in the ring closing of diethyl diallylmalonate, the dissociated pyridine ligands of $\mathbf{2}$ or $\mathbf{3}$ are unable to sufficiently stabilize the resting state of the active species, and thus these complexes are not particularly effective as catalysts.

Nevertheless, the pyridine-coordinated complexes in this work may find other applications. For example, $\left(\mathrm{H}_{2} \mathrm{IMes}\right)(\mathrm{py})_{2}(\mathrm{Cl})_{2} \mathrm{Ru}=\mathrm{CHPh}$ has been used as a precursor to other $\left(\mathrm{H}_{2} \mathrm{IMes}\right)(\mathrm{L})$ $(\mathrm{Cl})_{2} \mathrm{Ru}=\mathrm{CHPh}$ complexes, ${ }^{17}$ and a bis(pyridine) derivative with a chiral N-heterocyclic carbene ligand has been synthesized for its crystallization properties. ${ }^{9}$ We also note that two examples of ruthenium alkylidene complexes with tethered pyridine ligands have been reported recently. ${ }^{11,12}$ 


\section{Experimental Section}

General Procedures. All manipulations were performed using a combination of glovebox, high vacuum, and Schlenk techniques under a nitrogen atmosphere. Solvents were dried and degassed by standard procedures. NMR spectra were measured on Varian Inova 500, Varian Mercury 300, and JEOL JNM-GX400 spectrometers. ${ }^{1} \mathrm{H}$ NMR chemical shifts are reported in ppm relative to $\mathrm{SiMe}_{4}(\delta=0)$ and referenced internally with respect to the protio solvent impurity. ${ }^{13} \mathrm{C}$ NMR spectra were referenced internally with respect to the solvent resonance. ${ }^{31} \mathrm{P}$ NMR spectra were referenced using $\mathrm{H}_{3} \mathrm{PO}_{4}(\delta=0)$ as an external standard. Coupling constants are in hertz. Elemental analyses were determined by Midwest Microlab, Indianapolis, IN. Mass spectral analysis was performed at the Southern California Mass Spectrometry Facility (University of California, Riverside).

$\left(\mathbf{P C} \mathbf{y}_{3}\right)(\mathbf{p y})_{2} \mathbf{C l}_{2} \mathbf{R u}=\mathbf{C H P h}$ (2). A Schlenk flask was charged with $\left(\mathrm{PCy}_{3}\right)_{2} \mathrm{Cl}_{2} \mathrm{Ru}=\mathrm{CHPh} \quad(\mathbf{1}$; $0.200 \mathrm{~g}, 0.243 \mathrm{mmol})$ and toluene $(5 \mathrm{~mL})$. Pyridine $(500 \mu \mathrm{L}, 6.18 \mathrm{mmol}, 25 \mathrm{eq})$ was added by syringe, and the solution immediately changed from purple to green in color. The reaction was stirred at room temperature for $30 \mathrm{~min}$. The solution was transferred by cannula to another Schlenk flask with hexanes $(\sim 20 \mathrm{~mL})$ at $0^{\circ} \mathrm{C}$. The resulting light green precipitate was isolated, washed with cold hexanes, and dried under vacuum. ${ }^{1} \mathrm{H}$ NMR $\left(299.9 \mathrm{MHz}, \mathrm{CD}_{2} \mathrm{Cl}_{2}\right)$ : $\delta 19.90(\mathrm{~d}$, $1 \mathrm{H}, \mathrm{Ru}=\mathrm{CH},{ }^{3} J_{\mathrm{HP}}=12$ ), 8.76 (br s, $2 \mathrm{H}$, py), 8.38 (br s, $\left.2 \mathrm{H}, \mathrm{py}\right), 7.93$ (d, $2 \mathrm{H}, \mathrm{Ph}, J_{\mathrm{HH}}=7$ ), 7.64 (br m, 2H, py), 7.54 (t, 1H, Ph, $J_{\mathrm{HH}}=7$ ), 7.29 (br s, 2H, py), 7.18 (t, 2H, Ph, $J_{\mathrm{HH}}=7$ ), 7.09 (br s, 2H, py), 2.34 (app q, 3H, $\mathrm{PCy}_{3}$ ), 2.01 (br m, 6H, $\mathrm{PCy}_{3}$ ), 1.78-1.67 (br m, 15H, $\mathrm{PCy}$ ), 1.24 (br m, 9H, $\mathrm{PCy}) .{ }^{31} \mathrm{P}\left\{{ }^{1} \mathrm{H}\right\}$ NMR (161.9 MHz, $\left.\mathrm{CD}_{2} \mathrm{Cl}_{2}\right): \delta 37.71$ (s).

$\left(\mathbf{P C y} \mathbf{y}_{3}\right)(\mathbf{p y}) \mathbf{C l}_{2} \mathbf{R u}=\mathbf{C H P h}(\mathbf{3})$. A Schlenk flask was charged with $\left(\mathrm{PCy}_{3}\right)\left(\mathrm{py}_{2}\right)_{2} \mathrm{Cl}_{2} \mathrm{Ru}=\mathrm{CHPh}(\mathbf{2}$; $0.100 \mathrm{~g})$ and toluene $(5 \mathrm{~mL})$. The flask was placed in a $35^{\circ} \mathrm{C}$ oil bath, and the solvent was removed under vacuum to give an oily, yellow-green material. This material was washed with hexanes to remove the yellow-orange color and dried under vacuum to yield $\mathbf{3}$ as a dark green powder. ${ }^{1} \mathrm{H}$ NMR (299.9 MHz, $\mathrm{CD}_{2} \mathrm{Cl}_{2}$ ): $\delta 9.81\left(\mathrm{~d}, 1 \mathrm{H}, \mathrm{Ru}=\mathrm{CH}, J_{\mathrm{HP}}=12\right), 8.41$ (br s, $2 \mathrm{H}, \mathrm{py}$ ), $7.90\left(\mathrm{~d}, 2 \mathrm{H}, \mathrm{Ph}, J_{\mathrm{HH}}=7\right), 7.65$ (br s, $\left.1 \mathrm{H}, \mathrm{py}\right), 7.51\left(\mathrm{t}, 1 \mathrm{H}, \mathrm{Ph}, J_{\mathrm{HH}}=7.2\right), 7.18\left(\mathrm{t}, 2 \mathrm{H}, \mathrm{Ph}, J_{\mathrm{HH}}=\right.$ 7), 7.14 (br s, 2H, py), 2.34 (app q, 3H, $\mathrm{PCy}_{3}$ ), 2.01 (br m, 6H, $\mathrm{PCy}$ ), 1.78-1.67 (br m, 15H, $\mathrm{PCy}_{3}$ ), 1.24 (br m, 9H, PCy $) .{ }^{31} \mathrm{P}\left\{{ }^{1} \mathrm{H}\right\} \mathrm{NMR}\left(161.9 \mathrm{MHz}, \mathrm{CD}_{2} \mathrm{Cl}_{2}\right.$ ): $\delta 38.40$ (s).

$\left(\mathbf{P C y} \mathbf{y}_{3}\right)(\mathbf{p y})_{2}(\mathbf{C l})_{2} \mathbf{R u}=\mathbf{C H C H}=\mathbf{C P h} \mathbf{P}_{2} \mathbf{( 5 )}$. In the glovebox, a vial was charged with $\left(\mathrm{PCy}_{3}\right)_{2}\left(\mathrm{Cl}_{2^{-}}\right.$ $\mathrm{Ru}=\mathrm{CHCH}=\mathrm{CPh}_{2}(4 ; 0.300 \mathrm{~g})$ and pyridine $(5 \mathrm{~mL})$. The resulting brown solution was allowed to stand at room temperature for $30 \mathrm{~min}$. Hexanes were added $(\sim 25 \mathrm{~mL})$, and the vial was stored at $-10{ }^{\circ} \mathrm{C}$ for one week. The solvent was decanted, and brownish crystals of $\mathbf{5}$ were scraped from the sides of the vial, washed with cold hexanes, and dried under vacuum. ${ }^{1} \mathrm{H}$ NMR $(299.9 \mathrm{MHz}$, $\mathrm{C}_{6} \mathrm{D}_{6}$ ): $\delta 20.18$ (app t, $\mathrm{Ru}=\mathrm{CH},{ }^{3} J_{\mathrm{HP}}=12$ ), 9.17 (br, py), 9.09 (br, py), 8.81 (d, CH, $J_{\mathrm{HH}}=12$ ), $7.70\left(\mathrm{~d}, \mathrm{Ph}, J_{\mathrm{HH}}=7\right), 7.47$ (d, Ph, $\left.J_{\mathrm{HH}}=7\right), 7.46\left(\mathrm{~d}, \mathrm{Ph}, J_{\mathrm{HH}}=8\right), 7.22(\mathrm{~m}, \mathrm{Ph}), 7.10(\mathrm{~m}, \mathrm{Ph}), 6.97$ (br, py), 6.86 (t, Ph, $J_{\mathrm{HH}}=8$ ), 6.69 (br, py), 6.56 (br, py), 6.32 (br, py), 2.38 (br q, $\mathrm{PCy}_{3}, J_{\mathrm{HP}}=$ 10), 2.14 (br d, $\left.\mathrm{PCy}_{3}, J_{\mathrm{HP}}=11\right), 1.70\left(\mathrm{br}, \mathrm{PCy}_{3}\right), 1.59$ (br, $\mathrm{PCy}$ ), 1.13 (br m, $\mathrm{PCy}$ ). ${ }^{31} \mathrm{P}\left\{{ }^{1} \mathrm{H}\right\}$ 
NMR (121.4 MHz, $\left.\mathrm{C}_{6} \mathrm{D}_{6}\right): \delta 30.21(\mathrm{~s}) .{ }^{13} \mathrm{C}\left\{{ }^{1} \mathrm{H}\right\}$ NMR (125.7 MHz, $\left.\mathrm{C}_{6} \mathrm{D}_{6}\right): \delta 312.73(\mathrm{~m}, \mathrm{Ru}=\mathrm{C})$, 159.81 (s, py or $\mathrm{CH}=\mathrm{CPh}_{2}$ ), 158.79 (s, py or $\mathrm{CH}=\mathrm{CPh}_{2}$ ), 155.64 (s, py or $\mathrm{CH}=\mathrm{CPh}_{2}$ ), 153.79 (br, py or $\mathrm{CH}=\mathrm{CPh}_{2}$ ), 151.66 (br, py or $\left.\mathrm{CH}=\mathrm{CPh}_{2}\right), 147.80$ (s, py or $\left.\mathrm{CH}=\mathrm{CPh}_{2}\right), 144.86$ (s, py or $\mathrm{CH}=\mathrm{CPh}_{2}$ ), 142.92 (s, py or $\mathrm{CH}=\mathrm{CPh}_{2}$ ), 137.68 (s, py or $\mathrm{CH}=\mathrm{CPh}_{2}$ ), 136.15 (s, py or $\mathrm{CH}=\mathrm{CPh}_{2}$ ), 130.15 (s, py or $\mathrm{CH}=\mathrm{CPh}_{2}$ ), 129.63 (s, py or $\left.\mathrm{CH}=\mathrm{CPh}_{2}\right), 128.98$ (s, py or $\left.\mathrm{CH}=\mathrm{CPh}_{2}\right), 128.84$ (s, py or $\mathrm{CH}=\mathrm{CPh}_{2}$ ), 128.74 (s, py or $\mathrm{CH}=\mathrm{CPh}_{2}$ ), 128.69 (s, py or $\left.\mathrm{CH}=\mathrm{CPh}_{2}\right), 123.88$ (br, py or $\mathrm{CH}=\mathrm{CPh}_{2}$ ), 123.30 (br, py or $\mathrm{CH}=\mathrm{CPh}_{2}$ ), 123.27 (s, py or $\mathrm{CH}=\mathrm{CPh}_{2}$ ), 122.87 (s, py or $\left.\mathrm{CH}=\mathrm{CPh}_{2}\right), 37.00\left(\mathrm{~d}, \mathrm{PCy}_{3}, J_{\mathrm{CP}}=16\right), 36.10\left(\mathrm{~d}, \mathrm{PCy}_{3}, J_{\mathrm{CP}}=19\right), 29.99(\mathrm{~s}, \mathrm{PCy}), 28.66\left(\mathrm{~d}, \mathrm{PCy}_{3}\right.$, $J_{\mathrm{CP}}=10$ ). Anal. Calcd. for $\mathrm{C}_{43} \mathrm{H}_{55} \mathrm{Cl}_{2} \mathrm{~N}_{2} \mathrm{PRu}(802.87)$ : C, 64.33; H, 6.90; N, 3.49. Found: $\mathrm{C}$, 64.38; H, 6.95; N, 3.63 .

$\left(\mathbf{P C y}_{3}\right)(\mathbf{p y})_{2}(\mathbf{C l})_{2} \mathbf{R u}=\mathbf{C H C H}=\mathbf{C M e}_{2}(\mathbf{7})$. This compound was synthesized in the same manner as 5, except starting with $\left(\mathrm{PCy}_{3}\right)_{2}(\mathrm{Cl})_{2} \mathrm{Ru}=\mathrm{CHCH}=\mathrm{CMe}_{2}(\mathbf{6})$. As soon as isolated 7 was dissolved in $\mathrm{C}_{6} \mathrm{D}_{6}$, the solution began to change from green to orange-red in color. The NMR data for 7 was obtained within 10 minutes of preparing the sample. As decomposition progressed, free pyridine was observed by ${ }^{1} \mathrm{H}$ NMR. ${ }^{1} \mathrm{H}$ NMR $\left(499.9 \mathrm{MHz}, \mathrm{C}_{6} \mathrm{D}_{6}\right.$ ): $\delta 20.18$ (app t, $1 \mathrm{H},{ }^{3} J_{\mathrm{HP}}=10, \mathrm{Ru}=\mathrm{CH}$ ), 9.14 (br s, $4 \mathrm{H}, \mathrm{py}), 8.07$ (d, $\left.1 \mathrm{H},{ }^{3} J_{\mathrm{HH}}=12, \mathrm{CH}\right), 6.68$ (br s, 3H, py), 6.43 (br m, 3H, py), 2.54 (qt, $\left.3 \mathrm{H}, J_{\mathrm{HP}}=12, \mathrm{PCy}_{3}\right), 2.27\left(\mathrm{~d}, 6 \mathrm{H}, J_{\mathrm{HP}}=12, \mathrm{PCy}_{3}\right), 1.91\left(\mathrm{qt}, 6 \mathrm{H}, J_{\mathrm{HP}}=12, \mathrm{PCy}_{3}\right), 1.78\left(\mathrm{~d}, 6 \mathrm{H}, J_{\mathrm{HP}}\right.$ $\left.=11, \mathrm{PCy}_{3}\right), 1.62\left(\mathrm{~m}, 4 \mathrm{H}, \mathrm{PCy}_{3}\right), 1.26(\mathrm{~s}, 3 \mathrm{H}, \mathrm{Me}), 1.23\left(\mathrm{~m}, 8 \mathrm{H}, \mathrm{PCy}_{3}\right), 0.75(\mathrm{~s}, 3 \mathrm{H}, \mathrm{Me})$. ${ }^{31} \mathrm{P}\left\{{ }^{1} \mathrm{H}\right\}$ NMR $\left(121.4 \mathrm{MHz}, \mathrm{C}_{6} \mathrm{D}_{6}\right): \delta 37.17$ (s).

$\left[\left(\mathbf{P C y}_{3}\right)(\mathbf{1 - M e I m})_{3}(\mathbf{C l}) \mathbf{R u}=\mathbf{C H P h}\right][\mathbf{C l}] \mathbf{( 8 )}$. A Schlenk flask was charged with $\left(\mathrm{PCy}_{3}\right)_{2}(\mathrm{Cl})_{2}-$ $\mathrm{Ru}=\mathrm{CHPh}(1 ; 0.500 \mathrm{~g}, 0.608 \mathrm{mmol})$ and toluene $(15 \mathrm{~mL})$. 1-Methylimidazole $(0.250 \mathrm{~g}$, $3.045 \mathrm{mmol}$ ) was added with stirring. After $1 \mathrm{~h}$, the reaction mixture was allowed to settle, and the yellow supernatant was decanted from the green precipitate. This material was washed with toluene $(30 \mathrm{~mL})$ and dried under vacuum to provide of $8(0.437 \mathrm{~g}, 96 \%)$ as a bright green powder. The isolated material always included solvent that was not removed by vacuum; thus, a satisfactory elemental analysis could not be obtained. ${ }^{1} \mathrm{H}$ NMR $\left(499.9 \mathrm{MHz}, \mathrm{CD}_{2} \mathrm{Cl}_{2}\right): \delta 20.42$ $\left(\mathrm{d}, 1 \mathrm{H},{ }^{3} J_{\mathrm{HP}}=11, \mathrm{Ru}=\mathrm{CH}\right), 8.55(\mathrm{~s}, 2 \mathrm{H}, \mathrm{Im}), 7.65\left(\mathrm{~d}, 3 \mathrm{H}, J_{\mathrm{HH}}=9, \mathrm{Ph}\right), 7.47(\mathrm{~s}, 1 \mathrm{H}, \mathrm{Im}), 7.21(\mathrm{t}$, $\left.2 \mathrm{H}, J_{\mathrm{HH}}=8, \mathrm{Ph}\right), 6.99(\mathrm{~s}, 2 \mathrm{H}, \mathrm{Im}), 6.85(\mathrm{~s}, 2 \mathrm{H}, \mathrm{Im}), 6.53(\mathrm{~s}, 1 \mathrm{H}, \mathrm{Im}), 5.66(\mathrm{~s}, 1 \mathrm{H}, \mathrm{Im}), 3.70(\mathrm{~s}$, 6H, Me), 3.53 (s, 3H, Me), 1.89 (br, 6H, PCy $), 1.69$ (d, $\left.J_{\mathrm{HP}}=11,6 \mathrm{H}, \mathrm{PCy}_{3}\right), 1.59(\mathrm{~m}, 6 \mathrm{H}$, $\left.\mathrm{PCy}_{3}\right), 1.34$ (q, $\left.J_{\mathrm{HP}}=13,6 \mathrm{H}, \mathrm{PCy}_{3}\right), 1.16(\mathrm{~m}, 3 \mathrm{H}, \mathrm{PCy}), 0.88\left(\mathrm{~m}, 6 \mathrm{H}, \mathrm{PCy}_{3}\right) .{ }^{13} \mathrm{C}\left\{{ }^{1} \mathrm{H}\right\} \mathrm{NMR}$ $\left(125.7 \mathrm{MHz}, \mathrm{CD}_{2} \mathrm{Cl}_{2}\right): \delta 324.97(\mathrm{~m}, \mathrm{Ru}=\mathrm{C}), 152.35(\mathrm{~s}, \mathrm{Ph}), 141.92\left(\mathrm{~d}, J_{\mathrm{CP}}=35\right.$, trans $\left.\mathrm{Im}\right), 139.93$ $\left(\mathrm{d}, J_{\mathrm{CP}}=9\right), 138.21(\mathrm{~m}), 132.38(\mathrm{~s}), 132.19(\mathrm{~s}), 132.06(\mathrm{br}), 130.15(\mathrm{~m}), 129.60(\mathrm{~d}, J=9), 128.57$ $(\mathrm{m}), 121.45\left(\mathrm{~d}, J_{\mathrm{CP}}=18\right.$, trans $\left.\mathrm{Im}\right), 120.28\left(\mathrm{~d}, J_{\mathrm{CP}}=33\right.$, trans $\left.\mathrm{Im}\right), 36.00\left(\mathrm{~d}, J_{\mathrm{CP}}=15, \mathrm{PCy}_{3}\right)$, 35.13 (s, Me), 34.91 (s, Me), 29.55 (m, PCy $), 28.46$ (m, PCy $), 27.12$ (s, PCy $), 26.78\left(\mathrm{~s}, \mathrm{PCy}_{3}\right)$. ${ }^{31} \mathrm{P}\left\{{ }^{1} \mathrm{H}\right\}$ NMR (121.4 MHz, $\mathrm{CD}_{2} \mathrm{Cl}_{2}$ ): $\delta 22.77$ (s). HRMS (FAB) $\mathrm{m} / \mathrm{z}$ : calcd $\left[\mathrm{M}^{+}\right.$) 753.3114; found 753.3147 .

Crystallography. Crystal, intensity collection, and refinement details are presented in Table 1. Data were collected on a Bruker SMART 1000 area detector running SMART. ${ }^{24}$ The diffractometer was equipped with a Crystal Logic CL24 low temperature device, and the data sets were collected at low temperature $(98 \mathrm{~K})$ using graphite-monochromated MoK $\alpha$ radiation 
with $\lambda=0.71073 \AA$. The crystals were mounted on glass fibers with Paratone-N oil. Data were collected as $\omega$-scans with the detector $5 \mathrm{~cm}$ (nominal) distant at a $\theta$ of $-28^{\circ}$. The data were processed with SAINT. ${ }^{24}$ SHELXTL ${ }^{24}$ was used to solve (direct methods) and refine both structures using full-matrix least-squares. No decay correction was necessary.

The asymmetric unit for $\mathbf{5}$ consists of one molecule of $\mathbf{5}$ and one molecule of pyridine. All nonhydrogen atoms were refined anisotropically. Hydrogen atoms were refined isotropically.

The crystal of $\mathbf{8}$ was twinned, with the two components related by a two-fold rotation about $\mathrm{c}^{*}$. Each twin component was integrated separately. The merging R-factors for the major and minor twin components were 0.094 and 0.145 , respectively. Application of SADABS resulted in relative minimum and maximum transmission ranges of $1.000-0.7936$ and $1.000-0.6188$ for the major and minor twin component, respectively; this range is greater than expected for absorption and presumably results from integration problems due to peak overlaps The data files of both components were then combined using Gemini; reflections were grouped into three overlap categories with reciprocal difference vectors ranging between 0.000-0.007 (complete overlap, 15871 reflections), and two partial overlap bins (34129 reflections) with difference vector ranges of $0.007-0.014$ and $0.014-0.023 \AA$. Batch scale factors were refined for each group. The twin ratio refined to $1.8: 1$ based on completely overlapped reflections.

The asymmetric unit for $\mathbf{8}$ consists of two crystallographically independent molecules of $\mathbf{8}$ and multiple disordered dichloromethane molecules, which were modeled by approximately 4.42 molecules spread over four sites with occupancies of $1,1,1$, and 1.42. The fourth site contains a combination of three molecules; sometimes only one is present but never more than two are allowed due to steric considerations. All atoms were refined isotropically. Hydrogen atoms were placed at calculated positions (methyl groups were allowed to rotate) with displacement parameters based on those of the attached atoms. Graphics were prepared with the Diamond and SHELXTL programs. ${ }^{24}$

Crystallographic data (excluding structure factors) for the structures in this paper have been deposited with the Cambridge Crystallographic Data Centre as supplementary publication numbers 178708 (for 5) and 180988 (for 8). These data can be obtained free of charge via http://www.ccdc.cam.ac.uk/conts/retrieving.html (or from the CCDC, 12 Union Road, Cambridge CB2 1EZ, UK; fax: +44 1223 336033; e-mail: deposit@ccdc.cam.ac.uk). Structure factors are available from the authors by e-mail: xray@caltech.edu. 
Table 1. Crystal and structure refinement data for complexes 5 and $\mathbf{8}$

\begin{tabular}{|c|c|c|}
\hline Parameters & 5 & 8 \\
\hline empirical formula & $\mathrm{C}_{43} \mathrm{H}_{55} \mathrm{Cl}_{2} \mathrm{~N}_{2} \mathrm{PRu} \cdot \mathrm{C}_{5} \mathrm{H}_{5} \mathrm{~N}$ & $\mathrm{C}_{37} \mathrm{~N}_{57} \mathrm{~N}_{6} \mathrm{PCl}_{2} \mathrm{Ru} \cdot 2.21 \mathrm{CH}_{2} \mathrm{Cl}_{2}$ \\
\hline formula weight & 881.93 & 976.58 \\
\hline crystallization solvent & pyridine/hexanes & dichloromethane \\
\hline crystal habit & rhombohedral prism & block \\
\hline crystal color & dichroic gray/orange & aquamarine \\
\hline crystal size $\left(\mathrm{mm}^{3}\right)$ & $0.26 \times 0.19 \times 0.18$ & $0.22 \times 0.19 \times 0.15$ \\
\hline$a(\AA)$ & $10.5182(5)$ & $10.009(1)$ \\
\hline$b(\AA)$ & $15.3490(7)$ & $20.537(1)$ \\
\hline$c(\AA)$ & $15.5853(7)$ & $23.579(2)$ \\
\hline$\alpha(\mathrm{deg})$ & $107.345(1)$ & $77.477(1)$ \\
\hline$\beta(\mathrm{deg})$ & $103.806(1)$ & $81.799(1)$ \\
\hline$\gamma(\operatorname{deg})$ & $106.211(1)$ & $78.694(1)$ \\
\hline$V\left(\AA^{3}\right)$ & $2159.4(2)$ & $4014.0(5)$ \\
\hline$Z$ & 2 & 4 \\
\hline crystal system & triclinic & triclinic \\
\hline space group & $P-1(\# 2)$ & $P-1(\# 2)$ \\
\hline$\theta$ range for data collection (deg) & 1.50 to 28.30 & 1.78 to 28.55 \\
\hline absorption coefficient $\left(\mathrm{Mo}-\mathrm{K}_{\alpha}\right)\left(\mathrm{mm}^{-1}\right)$ & 0.561 & 0.756 \\
\hline reflections collected & 50107 & 48405 \\
\hline independent reflections & $9942\left[\mathrm{R}_{\mathrm{int}}=0.0464\right]$ & see experimental details \\
\hline no. parameters & 736 & 458 \\
\hline no. restraints & 0 & 9 \\
\hline treatment of hydrogen atoms & unrestrained & riding \\
\hline final $\mathrm{R}_{1}, w \mathrm{R}_{2}$ indices $[\mathrm{I}>2 \sigma(\mathrm{I})]$ & $0.0279,0.0560$ & $0.0874,0.1908$ \\
\hline $\mathrm{R}_{1}, w \mathrm{R}_{2}$ indices (all data) & $0.0343,0.0569$ & $0.0991,0.1924$ \\
\hline GOF on $\mathrm{F}^{2}$ & 1.872 & 2.423 \\
\hline largest diff. peak and hole (e. $\left.\AA^{-3}\right)$ & 0.73 and -0.40 & 2.93 and -2.10 \\
\hline
\end{tabular}

\section{Acknowledgments}

This research was supported by the U.S. National Science Foundation and the U.S. National Institutes of Health. T.M.T. appreciates a NDSEG graduate fellowship from the U.S. Department of Defense. We acknowledge Lawrence M. Henling for contributions to the crystallography, and we thank Drs. John P. Morgan and Jennifer A. Love for helpful discussions. 


\section{References}

1. Examples: (a) Love, J. A.; Morgan, J. P.; Trnka, T. M.; Grubbs, R. H. Angew. Chem., Int. Ed. 2002, 41, 4035. (b) Ulman, M.; Belderrain, T. R.; Grubbs, R. H. Tetrahedron Lett. 2000, 41, 4689. (c) Lynn, D. M.; Mohr, B.; Grubbs, R. H.; Henling, L. M.; Day, M. W. J. Am. Chem. Soc. 2000, 122, 6601. (d) Scholl, M.; Trnka, T. M.; Morgan, J. P.; Grubbs, R. H. Tetrahedron Lett. 1999, 40, 2247.

2. Dias, E. L.; Nguyen, S. T.; Grubbs, R. H. J. Am. Chem. Soc. 1997, 119, 3887.

3. Scholl, M.; Ding, S.; Lee, C. W.; Grubbs, R. H. Org. Lett. 1999, 1, 953.

4. Chang, S.; Jones, L.; Wang, C.; Henling, L. M.; Grubbs, R. H. Organometallics 1998, 17, 3460 .

5. Wu, Z.; Nguyen, S. T. Grubbs, R. H.; Ziller, J. W. J. Am. Chem. Soc. 1995, 117, 5503.

6. Schwab, P.; Grubbs, R. H.; Ziller, J. W. J. Am. Chem. Soc. 1996, 118, 100.

7. Nguyen, S. T.; Johnson, L. K.; Grubbs, R. H.; Ziller, J. W. J. Am. Chem. Soc. 1992, 114, 3974.

8. Sanford, M. S.; Henling, L. M.; Grubbs, R. H. Organometallics 1998, 17, 5384.

9. Seiders, T. J.; Ward, D. W.; Grubbs, R. H. Org. Lett. 2001, 3, 3225.

10. (a) De Clercq, B.; Verpoort, F. Adv. Synth. Catal. 2002, 344, 639. (b) Stüer, W.; Wolf, J.; Werner, H. J. Organomet. Chem. 2002, 641, 203. (c) Buchowicz, W.; Ingold, F.; Mol, J. C.; Lutz, M.; Spek, A. L. Chem. Eur. J. 2001, 7, 2842. (d) Coalter, J. N.; Caulton, K. G. New J. Chem. 2001, 25, 679. (e) Fürstner, A.; Ackermann, L.; Gabor, B.; Goddard, R.; Lehmann, C. W.; Mynott, R.; Stelzer, F.; Thiel, O. R. Chem. Eur. J. 2001, 7, 3236. (f) Garber, S. B.; Kingsbury, J. S.; Gray, B. L.; Hoveyda, A. H. J. Am. Chem. Soc. 2000, 122, 8168. (g) Katayama, H.; Urushima, H.; Nishioka, T.; Wada, C.; Nagao, M.; Ozawa, F. Angew. Chem. Int. Ed. 2000, 39, 4513. (h) Leung, W.-H.; Lau, K.-K.; Zhang, Q.-F.; Wong, W.-T.; Tang, B. Organometallics 2000, 19, 2084. (i) Saoud, M.; Romerosa, A.; Peruzzini, M. Organometallics 2000, 19, 4005. (j) Huang, J.; Stevens, E. D.; Nolan, S. P.; Petersen, J. L. J. Am. Chem. Soc. 1999, 121, 2674. (k) Weskamp, T.; Kohl, F. J.; Herrmann, W. A. J. Organomet. Chem. 1999, 582, 362. (1) Hansen, S. M.; Volland, M. A. O.; Rominger, F.; Eisenträger, F.; Hofmann, P. Angew. Chem., Int. Ed. 1999, 38, 1273. (m) Kingsbury, J. S.; Harrity, J. P. A.; Bonitatebus, P. J.; Hoveyda, A. H. J. Am. Chem. Soc. 1999, 121, 791. (n) Weskamp, T.; Schattenmann, W. C.; Spiegler, M.; Herrmann, W. A. Angew. Chem., Int. Ed. 1998, 37, 2490.

11. Denk, K.; Fridgen, J.; Herrmann, W. A. Adv. Synth. Catal. 2002, 344, 666.

12. van der Schaaf, P. A.; Kolly, R.; Kirner, H.-J.; Rime, F.; Mühlebach, A.; Hafner, A. J. Organomet. Chem. 2000, 606, 65.

13. Reviews: (a) Herndon, J. W. Coord. Chem. Rev. 2002, 227, 1. (b) Dragutan, V.; Dragutan, I.; Balaban, A. T. Platinum Metals Rev. 2001, 45, 155. (c) Trnka, T. M.; Grubbs, R. H. Acc. Chem. Res. 2001, 34, 18. (d) Jafarpour, L.; Nolan, S. P. J. Organomet. Chem. 2001, 617, 17. (e) Dragutan, V.; Dragutan, I.; Balaban, A. T. Platinum Metals Rev. 2000, 44, 58. 
14. (a) Sanford, M. S.; Ulman, M.; Grubbs, R. H. J. Am. Chem. Soc. 2001, 123, 749. (b) Sanford, M. S., Love, J. A., Grubbs, R. H. J. Am. Chem. Soc. 2001, 123, 6543.

15. Nguyen, S. T.; Grubbs, R. H.; Ziller, J. W. J. Am. Chem. Soc. 1993, 115, 9858.

16. Volland, M. A. O.; Rominger, F.; Eisenträger, F.; Hofmann, P. J. Organomet. Chem. 2002, $641,220$.

17. Sanford, M. S.; Love, J. A.; Grubbs, R. H. Organometallics 2001, 20, 5314.

18. Wilhelm, T. E.; Belderrain, T. R.; Brown, S. N.; Grubbs, R. H. Organometallics 1997, 16, 3867.

19. Trnka, T. M.; Morgan, J. P.; Sanford, M. S.; Wilhelm, T. E.; Scholl, M.; Choi, T.-L.; Ding, S.; Day, M. W.; Grubbs, R. H. J. Am. Chem. Soc. 2003, 125, 2546.

20. Fogg, D. E.; James, B. R. Inorg. Chem. 1997, 36, 1961.

21. Fürstner, A.; Picquet, M.; Bruneau, C.; Dixneuf, R. H. Chem. Commun. 1998, 1315.

22. (a) Baird, I. R.; Rettig, S. J.; James, B. R.; Skov, K. A. Can. J. Chem. 1998, 76, 1379. (b) Clarke, M. J.; Bailey, V. M.; Doan, P. E.; Hiller, C. D.; LaChance-Galang, K. J.; Daghlian, H.; Mandal, S.; Bastos, C. M.; Lang, D. Inorg. Chem. 1996, 35, 4896.

23. Batista, A. A.; Polato, E. A.; Queiroz, S. L.; Nascimento, O. R.; James, B. R.; Rettig, S. J. Inorg. Chim. Acta. 1995, 230, 111.

24. Bruker (1999) SMART, SAINT, and SHELXTL. Bruker AXS Inc., Madison, Wisconsin, U.S.A. Diamond 2.1. (2000) Crystal Impact GbR, Bonn, Germany. 